\title{
Renal arteriovenous fistula in Takayasu arteritis: a rare association deciphered on $\mathrm{CT}$ angiography
}

\author{
Mansi Verma 다, ' Vineeta Ojha (10 ,' Sanjeev Kumar, ${ }^{1}$ Pradeep Ramakrishnan ${ }^{2}$
}

${ }^{1}$ Department of Cardiovascular Radiology \& Endovascular Interventions, All India Institute of Medical Sciences, New Delhi, India

${ }^{2}$ Department of Cardiothoracic and Vascular Surgery, All India Institute of Medical Sciences, New Delhi, Delhi, India

\section{Correspondence to Dr Sanjeev Kumar; sanjeevradio@gmail.com}

Accepted 29 October 2021

\section{Check for updates}

(C) BMJ Publishing Group Limited 2021. No commercial re-use. See rights and permissions. Published by BMJ.

To cite: Verma M, Ojha V,
Kumar S, et al. BMJ Case
Rep 2021;14:e246983.
doi:10.1136/bcr-2021-
246983

\section{DESCRIPTION}

A 26-year-old woman who had a history of Takayasu arteritis (TA) presented with uncontrolled hypertension and bilateral lower limb claudication. The inflammatory markers as erythrocytic sedimentation rate and $\mathrm{C}$ reactive protein were raised. Plasma renin activity was increased with normal aldosterone-to-renin ratio. Doppler ultrasonography revealed parvus tardus waveform in the segmental arteries in bilateral kidneys. CT angiography done for the evaluation of aorta and its branches depicted diffuse circumferential mural thickening involving thoracic and abdominal aorta with short segment occlusion in the juxtarenal and infrarenal part. There was significant ostioproximal stenosis of the right renal artery. The left kidney was small, with occlusion of the left renal artery with distal reformation at the hilum. Interestingly, there was early opacification of the right renal vein (RV) on arterial phase images with an anomalous communication between right renal artery and RV at the hilum, suggesting a renal arteriovenous fistula (AVF). The right RV was dilated and was draining into inferior vena cava (figure 1). There was no history of preceding trauma and vascular or radiologic procedure done in the past. The patient was started on weight adjusted antihypertensive medication that included ACE inhibitor, beta blocker and a diuretic. For control of disease activity, prednisolone in a dose of $1 \mathrm{mg} / \mathrm{kg} /$ day was administered.

TA is a chronic, idiopathic inflammatory disease affecting aorta and its branches, pulmonary and

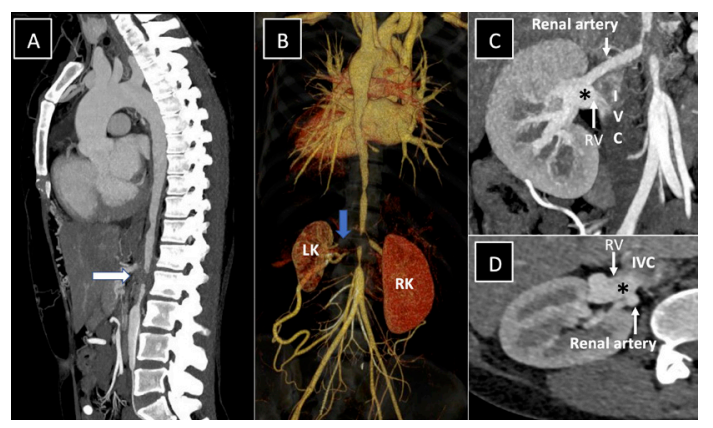

Figure 1 CT sagittal image (A) depicting diffuse mural thickening involving thoracic and abdominal aorta with occlusion of juxta renal aorta (white arrow). Volume rendered image as seen from posterior aspect (B) shows occlusion of left renal artery (blue arrow) with severe stenosis of ostioproximal right renal artery. Axial image $(C, D)$ in arterial phase reveals abnormal communication (fistula) between right renal artery and renal vein (RV) at hilum $\left(^{*}\right)$ with dilated right RV seen draining into inferior vena cava (IVC). LK, left kidney; RK, right kidney. coronary arteries. ${ }^{1}$ The imaging findings on CT angiography include concentric mural thickening, steno-occlusive lesions, ectasia and aneurysm formation. ${ }^{1}$ TA was first reported in 1908 by Mikito Takayasu with the typical wreath-like arteriovenous anastomosis around the optic disc. So, its nature includes arteritis and formation of arteriovenous shunt. ${ }^{2}$ In the setting of TA, coronary arterypulmonary artery fistulas have been described suggestive of extensive pulmonary artery involvement. However, to the best of our knowledge, there are no reports of renal AVF in TA in the literature. ${ }^{3}$ The primary causes of renal AVF include congenital abnormality, trauma and renal biopsy. However, in the present case, there were no predisposing factors. The kidneys have rich vascular supply with the renal artery and vein in close proximity to each other. So, a plausible explanation for formation of such an AVF could be diffuse vasculitis of arterial system with subsequent formation of fistula. ${ }^{4}$ This case highlights the importance of CT angiography in detecting rare vascular manifestations (such as AVF) in patients with TA.

\section{Learning points}

- The primary causes of renal arteriovenous fistula (AVF) include congenital abnormality, trauma and renal biopsy.

- The presence of renal AVF in Takayasu arteritis (TA) without any predisposing factor is very rare.

- $\mathrm{CT}$ angiography plays an important role in depicting such rare vascular manifestations in patients with TA.

Contributors All authors have participated sufficiently in the conception of the idea, development of the intellectual content, design, writing and final approval of the manuscript.

Funding The authors have not declared a specific grant for this research from any funding agency in the public, commercial or not-for-profit sectors.

\section{Competing interests None declared.}

Patient consent for publication Consent obtained directly from patient(s).

Provenance and peer review Not commissioned; externally peer reviewed.

Case reports provide a valuable learning resource for the scientific community and can indicate areas of interest for future research. They should not be used in isolation to guide treatment choices or public health policy. 


\section{REFERENCES}

1 Zhu FP, Luo S, Wang ZJ, et al. Takayasu arteritis: imaging spectrum at multidetector CT angiography. Br J Radiol 2012;85:e1282-92.

2 Takayasu M. A case with curious change in the central retinal vessel. J Jpn Ophthalmol Soc 1908;12:554-12
3 Ercan E, Tengiz I, Yakut N, et al. Takayasu's arteritis with multiple fistulas from three coronary arteries to lung paranchima. Int J Cardiol 2003;88:319-20.

4 Wang $\mathrm{H}$, Li J, Jiang Y, et al. Polyarteritis nodosa with multiple aneurysms and renal arteriovenous fistula successfully diagnosed by colour Doppler sonography. Clin Rheumatol 2013;32(Suppl 1):89-92.

Copyright 2021 BMJ Publishing Group. All rights reserved. For permission to reuse any of this content visit https://www.bmj.com/company/products-services/rights-and-licensing/permissions/

BMJ Case Report Fellows may re-use this article for personal use and teaching without any further permission.

Become a Fellow of BMJ Case Reports today and you can:

- Submit as many cases as you like

- Enjoy fast sympathetic peer review and rapid publication of accepted articles

- Access all the published articles

- Re-use any of the published material for personal use and teaching without further permission

\section{Customer Service}

If you have any further queries about your subscription, please contact our customer services team on +44 (0) 2071111105 or via email at support@bmj.com.

Visit casereports.bmj.com for more articles like this and to become a Fellow 